\title{
Obituaries
}

\section{William Silverman}

One of the founders of American neonatal medicine

Bill Silverman, sometime professor of paediatrics at New York's Columbia University, knew what it was to be at loggerheads with his peers, which is perhaps not surprising when you recall his capacity to speak his mind. "The impatient let's-try-it-and-see approach in the burgeoning field of neonatal medicine has resulted in therapeutic disaster after disaster," he wrote in a reflective memoir dated October 2003. His alternative was, of course, the randomised controlled trial (RCT). An early convert to the use of RCTs in obstetrics, Silverman remained a fervent advocate throughout a career that marked him out as one of the founders of American neonatal medicine.

In 1945, as a newly appointed instructor in general paediatrics at Columbia, he encountered his most formative influence: New York Babies Hospital neonatologist Richard Day. It was Day who taught Silverman how to base his clinical care on science. Day's own willingness to admit uncertainty in the absence of firm evidence had opened his mind to Bradford Hill's seminal work on medical statistics. Silverman caught the same bug and, as he describes in the memoir already quoted-written on his 86th birthday at the behest of the James Lind Library (www.jameslindlibrary.org/essays)"the two of us were soon making nuisances of ourselves by criticising the "in-myexperience' reasoning of our co-workers."

Through his involvement in the tragic saga of retrolental fibroplasia (retinopathy of prematurity), his devotion to rooting out weaknesses in clinical research methodology became more than an intellectual exercise. Although the condition had been described in the early 1940s, its cause was still a mystery when Silverman began practising. In 1949, when routine ophthalmoscopy revealed the first case in the Babies Hospital's recently opened premature infant unit, Silverman and his colleagues decided to clutch at the only straw to hand: the then new anti-inflammatory adrenocorticotrophic hormone (ACTH).

Relying on animal data they guessed the dose. The retinal vascular changes that signalled the onset of the disorder stopped, then began to recede. The child's vision was saved.

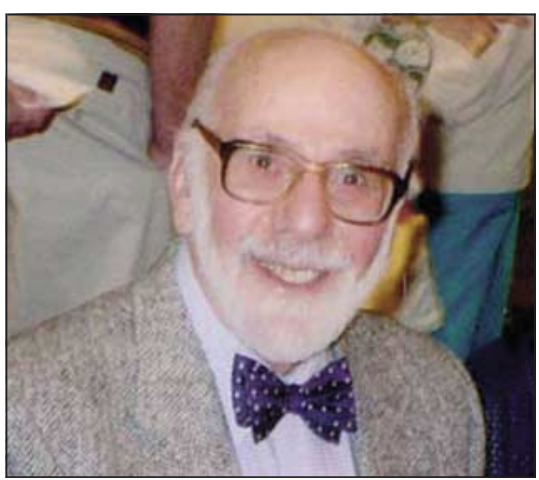

Encouraged, they used ACTH on a further 31 infants with the early signs of retrolental fibroplasia. Twenty five of them kept their vision. Although they were certain that ACTH was the right treatment, Silverman and Day felt obliged to subject it to the methodology that they had been preaching. They received permission to carry out an unprecedented experiment: a randomised controlled trial on neonates. The findings were devastating. A third of the treated babies became blind, but only a fifth of the control group. Not until the mid-1950s did further studies reveal that the actual cause of the blindness was the overliberal use of that apparently benign gas oxygen.

Following this experience, Silverman realised that "almost everything we were doing to care for premature infants was untested.” In a series of trials carried out over the next decade, he explored the influence of humidity, temperature, and other factors on life in an incubator. "I found these early exploitations of the power of randomised controlled trials very exciting," he wrote, "but I was increasingly aware that the statistical approach was anathema to free-wheeling doctors who resented any doubts being expressed about the effectiveness of their untested treatments." The studies he was constantly proposing evoked a condescension he described as "reductionist snobbery." A reductionist, he added, was an individual who, "when faced with Newton's problem to discover the source of gravity, cuts open the apple and looks inside."

The issue of optimum oxygen concentration for neonates in intensive care remains, even now, unsettled. While lowering the oxygen level certainly reduces the risk of retrolental fibroplasia, some believe it may also increase the chances of death following the prenatal period, or of survival with cerebral palsy. Silverman had been pointing to this possibility for decades. He must have been gratified to learn-albeit far too late, he would have said-that efforts were finally being made to tackle this question.

Having attained professorial status at Columbia, but frustrated by his inability to carry his subspecialty with him over the case for more adequate investigation, he resigned from his chair. He later became head of intensive care at the San Francisco Children's Hospital.

Evidence of the extent to which his ideas were no mere intellectual abstraction can be found in one of his subsequent occupations: working with the now young adults who had been blinded by retrolental fibroplasia. Could he have been seeking to atone for what he felt-wrongly-to have been his guilt in helping create their predicament? One friend and colleague who suspects he may have felt something like this is Iain Chalmers, now director of the James Lind Library in Oxford. Meeting Silverman in the 1970 s, he recognised a kindred spirit. He recalls Silverman's "deep bass voice that rang out when he spoke. A commanding voice."

Chalmers sees Silverman as "the conscience of the neonatal fraternity." Another admirer describes how "every ward round consisted of a huge debate from which everybody came away fired up to ask more questions."

Silverman met and corresponded with the philosopher Karl Popper, whom he quoted: “... if we respect truth, we must search for it by persistently searching for our errors..." The thought would serve well as Silverman's epitaph.

He leaves a wife, Ruth, and three children. [GEOFF WATTS]

William A Silverman, neonatologist New York and San Francisco (b Cleveland, Ohio, United States, 1917; q California 1942), died from renal failure in Greenbrae, California, on 16 December 2004.

Longer versions of these obituaries are available on bmj.com 


\section{John Gordon Uvedale Okeden Alexander}

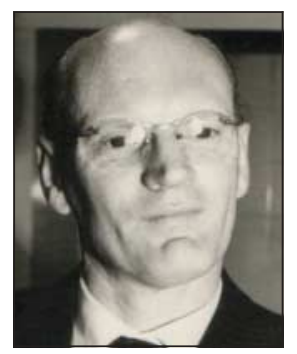

Former consultant microbiologist Hull and East Riding hospitals (b Caterham, Surrey, 1918; $q$ Middlesex Hospital 1942; FRCPath), d 29 September 2004.

After serving in the army, working in Italy and north Africa, Gordon became a pathology registrar in Liverpool. He was appointed consultant pathologist in the Hull area at the age of 32, and he designed and built the first virology laboratory there with the aid of his senior technician. In the late 1960s he developed a miniaturising technique of the serological testing of viral antibody titres (Journal of Clinical Pathology $1969 ; 22: 505)$, which is now common practice. He had several other publications relating to the diagnosis of enterovirus infections and described a new salmonella species isolated in a baby. He leaves a wife, June; three children; and four grandchildren. [Rosemary Alexander]

\section{James Maxwell Jones}

Former general practitioner Bridport and London, and medical missionary Lesotho (b China 1915; q King's College Hospital, London, 1938; FRCS Ed), d 4 December 2004. James Maxwell Jones was called up into the Royal Air Force Volunteer Reserve in 1940 and served as a medical officer until 1946, when he returned to general practice in Bridport. From 1961 to 1967 he worked at the Bethnal Green Medical Mission, London, before spending a year at St James's Mission Hospital, Lesotho, southern Africa, 7200 feet up in the Malute Mountains. His first wife died in Lesotho and he returned to the United Kingdom in 1969, working at the Islington Medical Centre, London, and the Bermondsey Medical Mission, until retirement from full practice in 1980. His Christian faith sustained him. He leaves his second wife, Doreen; six children; and 11 grandchildren. [DOREEN JonEs]

\section{Harold Stormont Ross}

Former consultant psychiatrist north-east Scotland (b Gorebridge 1926; q St Andrews 1952), died from cardiac failure on 20 August 2004.

Harold Ross was a nationally respected figure in the psychiatry of learning disability. He served in the Royal Air Force as a bomb aimer during the second world war. He was appointed deputy physician superintendent at the State Hospital, Carstairs, in 1957, and led the learning disability service in Fife before his appointment as physician in charge of this service for the north east of Scotland. Harold served on the Melville committee, which made far-reaching recommendations on the education of children with learning disabilities. He leaves a wife, Nessie, and three children. [Kathleen Ross, Robert Drummond]

\section{Alexander Bryce Stewart}

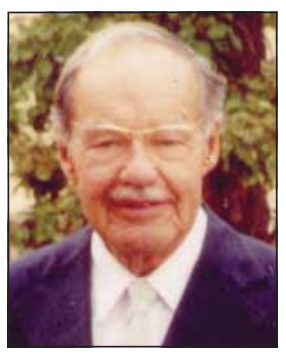

Former senior medical officer Department of Health (b 1916; q Durham 1941; FRCGP), died from bronchopneumonia following a stroke on 15 October 2004.

As a captain in the Royal Army Medical Corps he saw active service in the second world war, initially in Tunisia and after the D Day landings at Caen, Nijmegen, and Arnhem. He later served as a medical officer in Belsen. After the war he purchased what had previously been his father's medical practice in Bury, Lancashire. He joined the then Department of Health and Social Security 14 years later. His final post was as senior medical officer heading the southern division of the regional medical service. He was an accomplished sailor. He leaves a wife, Vera, and four children. [STEWART MundaY]

\section{Monnica Charlotte Stewart}

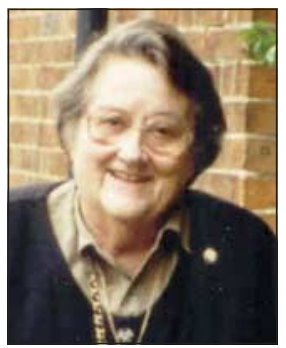

Former principal medical officer (adult health) Basingstoke and North Hants (b 1924; $q$ Durham 1950; DObst RCOG), died from cardiac failure on 14 October 2004 a few hours before her brother, Dr Alexander Bryce Stewart (obituary above).

After working in obstetrics in Newcastle upon Tyne, Farnborough, and Newport, Isle of Wight, she changed direction to geriatrics when appointed assistant physician at Edgware General Hospital. She worked for Newham within community medicine and was later appointed principal medical officer for Basingstoke and North Hants. She published My Brother's Keeper in 1968, which anticipated and highlighted future problems for geriatric medicine and home care support. She retired in 1989. [STEWART MUNDAY]

\section{Harry Berrington ("Berry") Stoner}

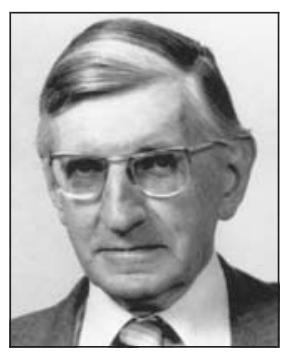

Former director Medical Research Council trauma unit, Manchester (b 1919; q Sheffield 1942; MD, FRCPath, FRCS), d 9 July 2004.

Professor Harry Berrington Stoner was a world authority in trauma research. In 1953 he became head of the MRC experimental pathology of trauma unit in Carshalton, Surrey. The work on shock carried out at Carshalton was the focus of worldwide attention, but after 20 years was reaching its limits because it was confined to animal experimentation. The chance to transfer it to a clinical environment came with the creation at Manchester University of the MRC trauma unit. Major clinical outcomes of Stoner's work here included the development of an acclaimed sepsis scoring system. He leaves a daughter and two grandchildren. [Miles Irving]

\section{Kolappa Sundararajan}

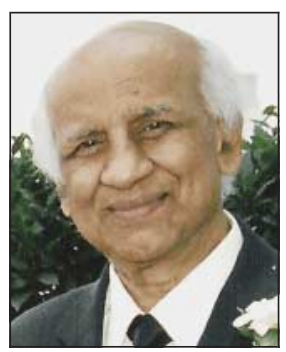

Former senior consultant psychiatrist Halifax and Surrey (b south India 1928; $q$ Madras 1954; DPM, FRCPsych, FRSH, FRS),

d 8 December 2004.

Dr Raj, as he was known, became a consultant to Calderdale Health Authority in 1974. He was chairman of the division of psychiatry and was a member of the specialists advisory committee for Yorkshire. He lectured students, was engaged in numerous medical research projects and published numerous papers. After retiring in 1995 he moved to Surrey, where he continued to be active in locum work and was able to concentrate more on supporting his charities. He leaves a wife, Ranjini; three daughters; and two grandchildren. [P SUNDARARAJAN] 